\title{
Records on some lower fungi occurring in mites (Acarina) from Poland
}

\author{
STANISI.AW BALAZY*, JERZY WISNIEWSKI**
}

Department of Agricultural and Forest Biology. Polish Academy of Sciences", ul. Szecherezady 74. 60-184 Poznań. Poland; Chair of Forest and Environment Pr Iection**, Academy of Agriculture. ul. Wojska Polskiego $71 \mathrm{c}, 60-625$ Poznan, Poland

Batazy S. W is niewski J. Recerds on sone lower fungi occarring in mites (Acarina) from Poiand. Acta Mycol, 20 (2) 159-172, 1984

As result of the investigations on fungal discases of the mites cocurring in ant hills. forest litter and galleries of subcortical insects 12 species of the fungi have been recorded. The majority of them are the resting spore stages of Emopmophitaraceve from the genus Taricham Cohn; 9 new species of this genus have been describod and the tabular comparison of their morphological features has becn estimated.

\section{INTRODUCTION}

The majority of so far published data on fungal diseases of mites (Acarina) concerns the phytophagous species of the families Tetranychidae and Eriophyidae. The mycoses of others have been mentioncd circumstantially or occasionalIy, often without any precise determination of the pathogen species. This results from the fact that the acarologists in general pay too little attantion to the problem of invertebrate pathology. A review of the reference of this field is given by Lipa $(1962,1971), \mathrm{Nem} \mathrm{to}$ and $\mathrm{A} \mathrm{OK} \mathrm{i} \mathrm{(1974)} \mathrm{and} \mathrm{supplemented}$ by Tsintsadze and Vartapetov (1976), Ba tazy and Wisniewski $(1977,1983)$ and $\mathrm{Egina}$ and $\mathrm{Tsinovskii}(1980)$

\section{MATERIALS AND METHODS}

In the years 1975 - 1983 acarologic materials were gathered mostly from ant nests and forest litter as well as from the galleries of subcortical insects. During the taxonomical claboration of these collections several dozen od the mites with 


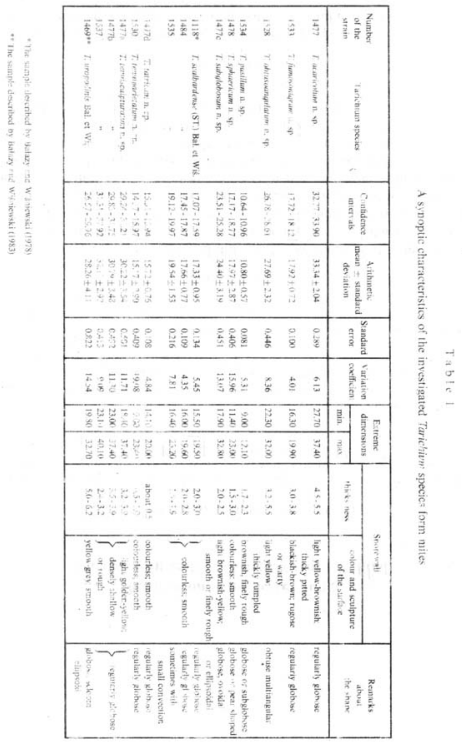


signs suggesting intections witt. enthomopathogenic fungi were separated. The majority of the mites collected were put into $70 \%$ alcohol, which made impossible the observation of the development cycle of the pathogens. Efforts wers made to rediscovery of intected mutes in the known loulities. However, such endert ours as well as rtrempis at isolation and laboratory culturing of pariculat fungal strains were usually unsuccessful.

The mites with their pathogens were prepared in lactophenol often wit: aniline blue staining; sometimes also aceto-carmine was applied. Infected species were oftel devoid of their extremities or even gnathosoma, which made the determination of the host species very difficult or entirely impossbic. The characteristics of the fungi were prepared on the basis of the accessible elements of their morphology. The resting spores of particular samples have been compared with respect to their general morphology, colour, thickness and ornamentation of the epispore and dimensions based on 50 measurements, considering the standard deviation and standard error of the arithmetic mean and the range of variability (Table 1). Such characteristics of two species of Tarichium from mites described earlier are also included. The materials includin: the types of ncwly described species have been preserved in the Department of Agricultural and Forest Biology of the Polish Academy of Sciences in Poznań.

\section{RESULTS AND DISCUSSION}

Among numerous forms of the fungi developing as necrophytes on dead mites or on separate parts of their exoskeletons the hyphomycetes were the most common. Their hyaline or dematiaceous mycelia usually grew superficially giving often abundant conidial sporulation. The majority of the isolated strains were determined as Acremonium spp., Acrodontium crateriforme (v. Beyma) de Hoog, Asperqillus sp., Botrytis cinerea Pers. ex Nocca et Balb., Cladosporium spp., Hormiscium sp., Oedocephalum sp., Penicillium spp., Sporothrix sp., Trichoderma spp. Virgaria sp. and some others, occurring commonly on dead insects, too (K o v a 1 1974; B a \& a z y 1976). Only the species Hirsutella thompsoni Fisher and a number of the strains related to Verticillium lecanii (Zimm.) Viegas seemed to show some pathogenic relationships to their hosts. However, the aim of the present work has been the separation of the forms of the lower fungi which should be able to infect, develop, and sporulate in mites. Thus, elements having a character of the resting spores found usually in great numbers inside the mites and - in all appearences - related to the family Entomophthoraceae as the representatives of the provisional genus Tarichium Cohn are considered here. in the recent monographs of the Entomophthoraceae including that of Iarichium (M a c L e o d. M ü Il e r-K ög l e r 1970) only few species form mites 
have been included, which do not allow to identify the majority of the forms obtained by means of the comparison. Consequently, a number of the forms were described as new species. Some samples contained the material inconvenient for the full identification or sure description of the species. In such cases only some suppositions as to the taxonomy of the fungi have been expressed.

\section{IDENTIFIED OR NEWLY DESCRIBED SPECIES}

Erynia phalangidia (Lagerh.) Rem. et Kell. (PL I)

The mycelium on the host's body surface cream-white, radially setose, consisting of the conidiophores about $10 \mu \mathrm{m}$ thick, richly digitately branched in their top parts (PI. I) intermixed with numerous straight pseudocystidia about 18 $\mu \mathrm{m}$ thick at the basis and gradually narrowing to $8 \mu \mathrm{m}$ below the slightly inflated, obtuse tip, sticking out $250-350 \mu \mathrm{m}$ over the sporulating layer of the mycelium (Pl. Ic). The primary conidia ovoidal with slightly convex papilla 4.5-6,0 $\mu \mathrm{m}$ wide, monokaryotic, bitunicate, (18.1)-20.0-21.9 $\times 10.5-12.4 \mu \mathrm{m}$, with strongly vacuolized content. The secondary conidia smaller, 14.4-18.7 $\times$ $\times 10.0-11.7 \mu \mathrm{m}$ stronger narrowed towards the semispherically convex papilla $3.8-4.7 \mu \mathrm{m}$ wide. The host attached to the substrate with few unbranched, ribbon-like rhizoids $12-20 \mu \mathrm{m}$ wide, expanded at ends into disc-like structures with deeply sinuose margins. Inside host's body the irregularly branched segments of the hyphae, $6-12 \mu \mathrm{m}$ in diameter, and globose azygospores (25.7)-27-34-(36.7) $\mu \mathrm{m}$, with the wall smooth, $0.5-1.0 \mu \mathrm{m}$ thick, occurred. The regularly finely granular content of the resting spores easily staining with aniline blue in lactophenol indicates that they were still unripe. This fungus was found on 20 A ugust 1976 in the Wielkopolski National Park, protected district Jeziory, on a dead female of the mite Pergamasus septentrionalis (Oud.) (det. Dr. W. $\mathrm{M} \mathrm{i} \mathrm{c} \mathrm{h}$ e r d z in s k i) attached to the underside of a leaf of Tussilago farfara in the deciduous forest undergrowth (Galio sileatici-Carpinetum).

The morphology of this fungus agrees cntirely with the description of Entomophthora phalangicida Lagerheim, known from harvest spiders (Opiliones, Phalangiidae) in two localities in Sweden. L a g e r h e i m (1898) did not give any information concerning resting spores. In spite of extremely careful se rches carried on in the described locality in the Wielkopolski National Park till 1982 , directed to the fungous diseases of small insects, mites and harvest spiders (B a I a z y 1978, 1982 a. b) the discussed fungus has not been found again. In nurphological respect this fungus shows some affinities with some other Erynia species pathogenic for insects - e.g. E. dipterigena (Thaxt.) Rem. et Henneb., E. dacnusae Bat. - however, up to date there have not been worked out any sure 
criteria for the differentiation of the similar species in this enus. Thus, at least up to the moment of more precise determination of the parasitic specialization and physiology of nutrition of the fungi of this group, particular strains originating from distant hosts and showing simultaneously certain morphological differences should be treated as different species. From among entomophthoracean species so far described from mites Empusa acaridis Petch seems to be the closest to the genus Erynia. However, incomplete data on the character of the conidiophores and pseudocystidia as well as the lack of the rhiz ids underlined in the description (P e t c h 1944: 87) make impossible any comparisons.

\section{Tarichium acaricolum n. sp.}

Resting spores light yellow-brownish, regularly globose, of the diameter (27.7)-32.8-33.9-(37.4) $\mu \mathrm{m}$, with the wall $4.5-5,5 \mu \mathrm{m}$ thick and the epispore regularly thickly pitted. A condensed protoplasm forms a thin layer around the great, transparent central vacuole. The resting spores fill the host's body cavity together with the basal parts of its legs. The conidial sporulation, rhizoids and pseudocystidia lacking.

In dead mite Pergamasus sp. found under the Scotch pine bark on 16 May 1981 in the forest district Zielonka, forestry Zielonka. The type signed with the $\mathrm{N}^{\circ} .1477$ in the collection.

Diagnosis ( $\mathrm{Pl}$. II a-b). Sporae perdurantes regulariter globosae, pallide brunneo-flavae, diametro (27.7)-32.8-33.9-(37.4) $\mu \mathrm{m}$, cum membrana externa $4.5-5.5 \mu \mathrm{m}$ crassa, superficie regulariter forte sinuat a, corpus hospitis cum basalibus extremitatum articulis complent. In sporis centralis hyalina vacuola tenui densae plasmae strato continetur.

In mortuo Pergamasus specie (Acarina) sub cortice Pini in silva Zielonka prope Posnaniam die 16 mense Maio anno 1981 coll. Typus numero 1477 in collectione designatus.

In the available references no description of Tarichium species corresponding with the above morphological characteristics has been found.

\section{Tarichium fumosonigrum n. $\mathrm{sp}$.}

Resting spores regularly globose, dark brownish or smoky black of the diameter (16.3)-17.7-18.1-(19.9) $\mu \mathrm{m}$ with the wall 3.0-3.8-(4.0) $\mu \mathrm{m}$ thick and the epispore rugose, warty or in some parts spinulose. The content formless. undifferentiated or thickly granular. The resting spores fill the posterior half of host's body. Vegetative mycelium and conidial sporulation lacking. 
In the dead mite Pergamasus sp. devoid of legs and gnathosoma, found in the hill of Formica polyctena Först. in the coniferous forest Potasze, forest district Zielonka on 16 March 1964. The type signed with the $\mathrm{N}^{\circ} .1533$ in the collection.

Diagnosis ( $\mathrm{Pl}$. II c-d). Sporae perdurantes regulariter globosae, obscuro-brunneae vel fumoso-nigrae diametro (16.3)-17.7-18.1-(19.9) um cum membrana $3.0-3.8-(4.0) \mu m$ crassa episporio ruguloso vel verrucoso in nonnullis locis spinuloso. posteriorem partam corporis hospitis implent. In sporis materia hyalina indiferens. Mveelium et sporulatio conidialis desunt.

In mortuo Pergamasus sp. (Acarina) in cuniculo Formicae polyctenae in silva conifera Potasze prope Posnaniam die 16 mense Martio anno 1964 coll. Typus numero 1533 in collectione designatus.

The distinctive features of this species are the colour, surface sculpture and dimensions of the resting spores.

\section{Tarichium obtusoangulatum n. sp.}

Resting spores in outline irregularly circular or obtuse multiangular, light yellow, of the diameter (22.3)-26.8-28.6-(32.0) $\mu \mathrm{m}$ with the wall 3.2-5.5 $\mu \mathrm{m}$ thick; the epispore thickly and deeply rumpled with numerous obtuse conical convexities. The content formless, transparent. The resting spores fill the body cavity of a host.

In a dead mite Uropoda minima Kramer found under the Scotch pine bark in the moist coniferous forest Kosobudki, forest district Krosno Odrzańskie on 22 September 1982. The type signed with the number 1528 in the collection.

Diagnosis ( $\mathrm{PL}$. III a-b). Sporue perdurantes in lineamentis irregulariter irculares vel obtuso-muitianqula:ae, pallido-flatae, diametro (22.3)-26.8-28.6-(32.0) im cum membrana 3.2-5.3 um crussa, episporto cum obtuso-conoideis contexitatibus valde et profunde sinuato. In sporis materia hyalina indiferens. Sporulatio conidialis ot myceliom desumt.

In mortuo Uropodis minimae sub cortice Pini in silva conifera Kosobudki prope Krosno Odrzaniskie die 22 mense Septembri anno 1982 coll. Typus numero 1528 in collectione designatus.

This species differs from T. acaricolum $\mathrm{n}$. sp. by distincly smaller resting spores and considerably stronger, irregular folding of their epispore.

\section{Tarichium pusillum n. sp.}

Resting spores globose or subglobose (9.0)-10.6-11.0-(12.1) $\mu \mathrm{m}$ in diameter with grey-yellow wall $1.7-2.3 \mu \mathrm{m}$ thick, covered by a very thin, finely rough, brownish epispore. The content coarse-grained and irregularly vacuolized. The spores very numerous fill the body cavity and basal parts of host's legs. 

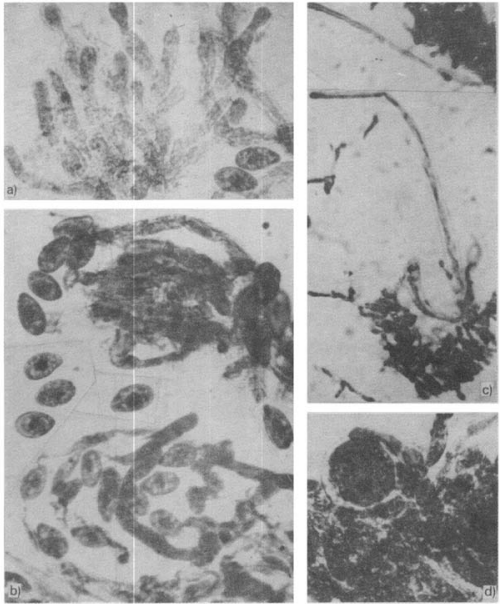

\section{Plate I}

Erynia phalangicida (Lagerb.) Rem. et Kell.

$a$ - terminal branching of a conidiophore: $b$ - external mycelium and conidia; $c$ - pseudocystidia: $d-$ internal mycelium with a resting spore 

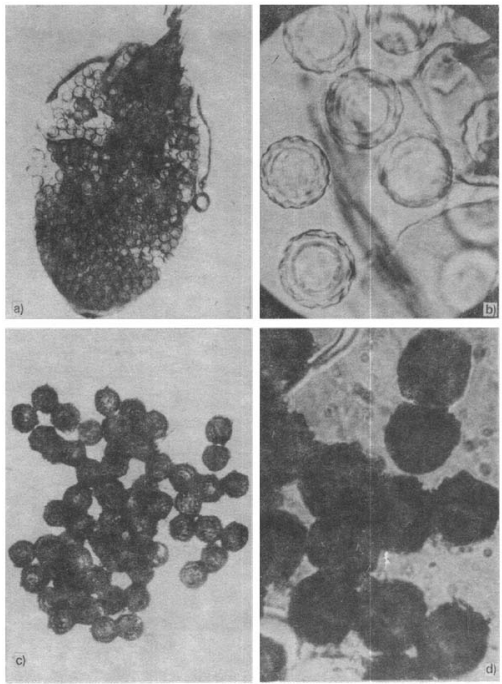

Plate II

$a-b-$ Tarichium acaricolum n. sp. - resting spores; $c-d$ - T. fuenosonigram n. sp. - resting spores 

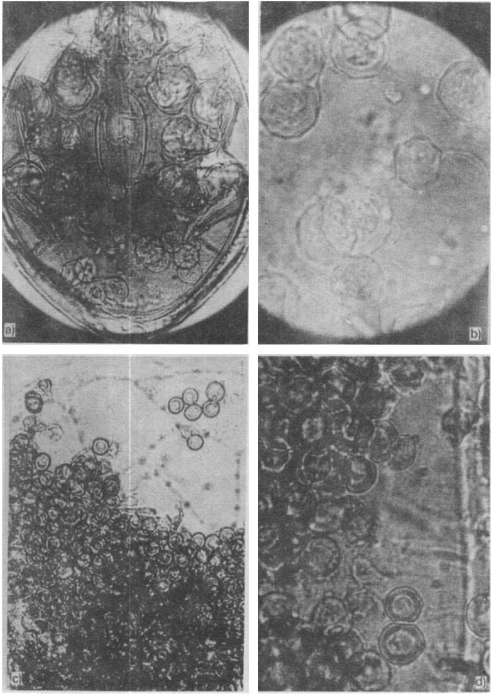

Plate III

$a-b$ - Tarichium obtusoangularum n. sp. - resting spores; $c-d-$ T. pusillum n. $\mathrm{sp}$. - resting spores 


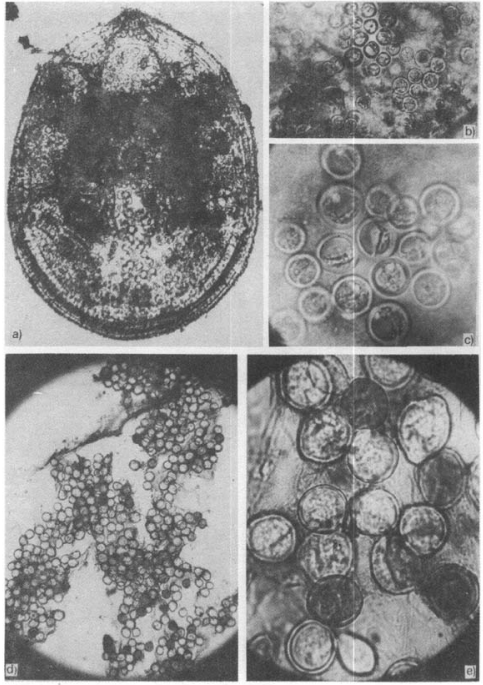

Plate IV

a-c - Tarichum sphacricum n. sp. - resting spores; $d-e-r$ subgtaboxim n. sp. - resting spores 

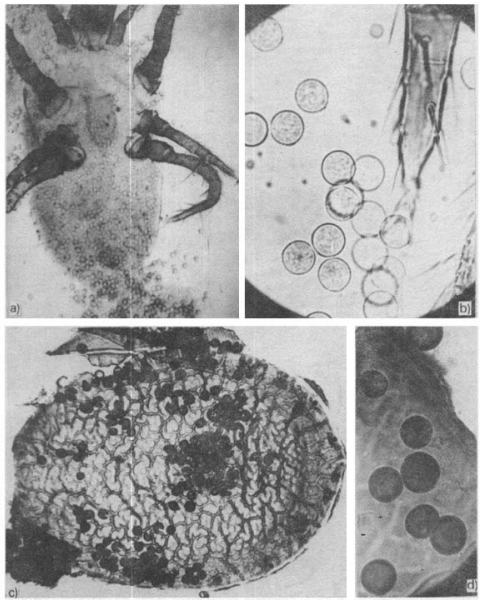

Plate V

$a-b$ - Tarichtum fatrictm n. sp - resting spores; $c * d-T$ tenuiparietatum n. sp. - resting spores 

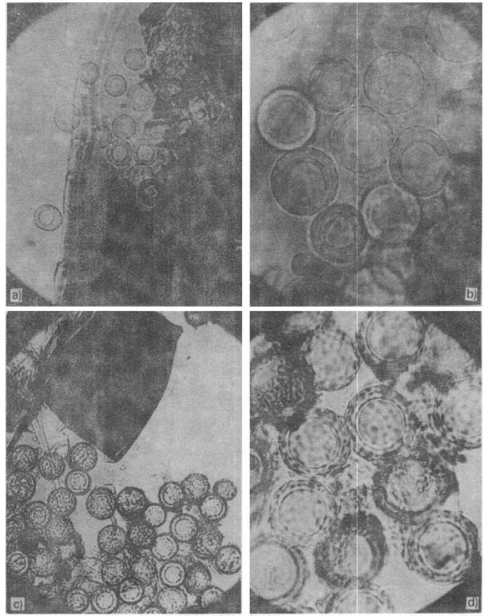

\section{Plate VI}

a-d - Tarichium tenuisculpturatum n. sp. - resting spores, $a-b$ - specimen N $\mathrm{N}^{\circ} .1477 \mathrm{a}, c-d-$ specimen $\mathrm{N}^{\circ}, 1477 \mathrm{~b}$ 

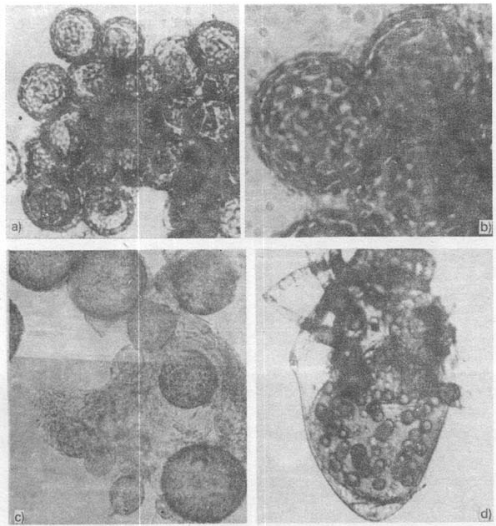

d)
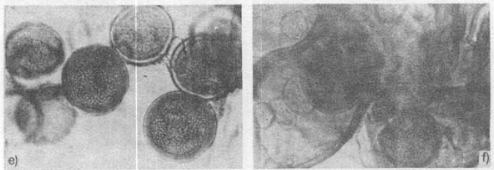

Plate VII

Tarichilum tentrisculpturetum $\mathrm{n}$. $\mathrm{sp}$

$a-b$ - resting sporss of the specimen $\mathrm{N}^{\circ} .1537$ (magnif. ineompar. with Plate VI) Pythium-like mycelium with durable structures

$c$ - elements of vegetative phase, $d$ - thick-walled structures inside Pergamasus sp; $e$ - durable structures from the body cavity; $f$ - thick-walled structures inside articles of egs (note the presence of thin-walled outlines of degenerated cells) 

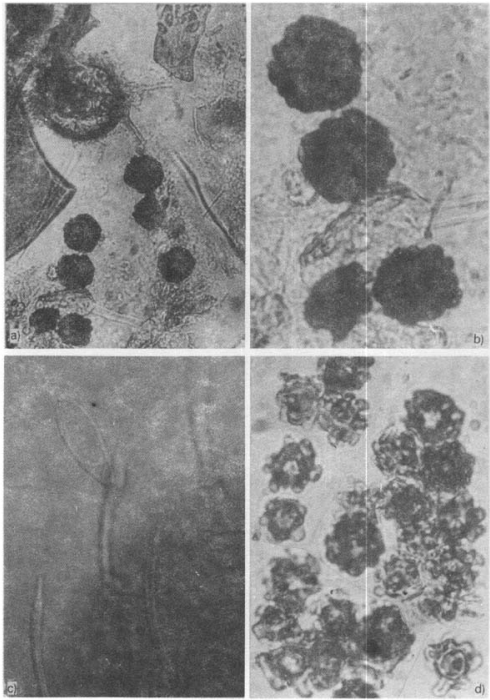

Plate VIII

Unidentified forms of fungi from mites

$a=b$ - Tarichium-like structures from a dead Oribatei $c$ - a capillispore of Neozygites $\mathrm{sp}$ (Triplosporium sp.) attached to a seta of Parasitiformes-deutonymph; $d$ - zygospores of a species of Zovipadales from a dead Perganasus sp. 
In a dead mite Pergamasus sp. from the rotten ash wood, collected on 27 March 1983 in the park of the bee-hive Skansen museum in Swarzędz near Poznan. The type signed with the number 1534 in the collection.

Diagnosis (Pl. III c-d): Sporae perdurantes globosae vel subglobosae diametro (9.0)-10.6-11.0-(12.1) $\mu \mathrm{m}$. corpus hospitis cum basalibus extremitatum articulis complent. Membrana externa glauco-flava 1.7-2.3 $\mu$ m crassa cum tenue ruguloso episporio brunneo. Muteria interna irregulariter granulata.

In mortuo Pergamasus specie (Acarina) ex ligno putrido Fraxini excelsioris in horto musei apidarii Swarzędz prope Posnaniam die 27 mense Martio anno 1983 coll. Typus numero 1534 in collectione designatus.

This species differs from all others described here as well as from the forms reported in references ( $\mathrm{T}$ h or $1930, \mathrm{M}$ a c L e o d and $\mathrm{M}$ ü $1 \mathrm{le} \mathrm{r}-\mathrm{K}$ ö $\mathrm{g}-$ le r 1970) by small and very constant dimensions of the resting spores.

\section{Tarichium sphaericum n. sp.}

Resting spores smooth, colourless, globose, diameter (11.4)-17.2-18.8$-(23.0) \mu \mathrm{m}$, seldom ellipsoid or pear-shaped 17.9-26.3 × 12.7-17.2 $\mu \mathrm{m}$, with the wall 1.5-3.0 $\mu \mathrm{m}$ thick. The content transparent: the protoplasm sourrounds a big central vacuole with thin, one-sided a little thicker layer. The resting spores fill the host's body cavity not coming into basal parts of legs. Vegetative mycelium unobserved.

In the dead mite Trachyuropoda coccinea (Michael) from the nest of Formica polyctena Först., found in the coniferous forest Potasze, forest district Zielonka, on 8 October 1981. The type signed with the $\mathrm{N}^{\circ} .1478$ in the collection.

Diagnosis (PI. IV a-c). Sporae perdurantes leves hyalinae, globosae, diametro (11.4)-17.2-18.8-(23.0) $\mu \mathrm{m}$, raro ellipsoides vel piriformes 17.9-26.3 $\times 12.7-17.2 \mu \mathrm{m}$, cum membrana 1.5-3.0 um crassa in extremitatum articula non venientes, corpus hospitis implent. In sporis centralis vacuola tenui semilunoideoque plasmae strato continentur.

In mortua Trachyuropoda coccinea (Acarina) in cuniculo Formicae polyctenae in silua conifera Potusze prope Posnaniam die 8 mense Octobri anno. 1981 coll. Typus numero 1478 in collecrione designatus.

The resting spores of this species occurring in mass resemble the illustrations given by $\mathrm{T}$ h or (1930) for the species Arctosporidium lucidum ST, considered as belonging to Haplosporidia. As a result of comparisons of the features distinctive differences have been found particularly in the dimensions and protoplasmatic content of the resting spores. Thus, although according to the statements of L in d q u is t (1961), S a m š in á $\mathrm{k}$ (1962) and $\mathrm{Lipa}$ 
(1962, 1971) $\mathrm{T}$ h o $\mathrm{r}$ 's species represent in reality a resting spore form of an entomopathogenic fungus, it cannot be considered as conspecific with the specimen found in Trachyuropoda coccinea.

\section{Tarichium subglobosum n. sp.}

Resting spores smooth or finely rough, globose of the diameter (17.9)-23.5$-25.3-(32.8) \mu \mathrm{m}$ or ovoidal to broadly ellipsoid $21.0-30.5 \times 17.2-25.0 \mu \mathrm{m}$, often with a smal papilliform convexity, sometimes one-sided stronger narrowed somewhat pyriform, light brownish-yellow, with the wall 2.0-2.5 $\mu$ m thick. The content granular, yellowish. The resting spores numerous both in the host's body cavity and in its legs. Conidial sporulation, pseudocystidia and rhizoids lacking.

In a dead mite Pergamasus sp. from a hill of Formica rufa found in the coniferous forest Piotrowo, forest district Oborniki on 20 Mai 1982. The type signed with $\mathrm{N}^{\circ} .1477 \mathrm{c}$ in the collection.

Diagnosis (Pl. IV d-e). Sporae perdurantes leves vel tenui asperatae, globosae diametro (17.9)-23.5-25.3-(32.8) $\mu \mathrm{m}$ vel late-ellipsoideae 21.0-30.5 $\times 17.2-25.0 \mu \mathrm{m}$, saepe cum parva papilliformi convexitate, nonnumquam ex una parte angustiores, paulo piriformes, pallide brunneo-fulvae, cum membrana 2.0-2.5 $\mu \mathrm{m}$ crassa, corpus hospitis una cum extremitatibus complent.

In mortuo Pergamusus sp, in cuniculo Formicae rufae, in silva ce nifera Piotrowo prope Oborniki die 20 mense Maio anno 1982 coll. Typus numero $1477 \mathrm{c}$ in collectione designatus.

The material was kept in the laboratory in living state but attempts at isolation of the fungus on media as well as efforts for obtaining its other morphological elements or developmental stages failed. The characteristics of this fungus do not correspond with any of so far described species.

\section{Tarichium svalbardense (ST.) Bait. et Wis.}

This species has been exactly described and discussed in a separate paper (B a ła z y and W iśn i ewski 1977). The same species was identified lately in a dead mite Pergamasus sp. collected under the bark of spruce trunk in the coniferous forest Rakownia, forest district Zielonka, on April 7, 1982.

Another specimen was found on March 30, 1983 in a dead oribatid mite taken out from the rotten wood of the hollow in Robinia pseudacacia L. in the Dendrological Garden of the Academy of Agriculture in Poznan-Solacz. Its resting spores were of about $2 \mu \mathrm{m}$ larger diameter (Table 1, $\mathrm{N}^{\circ} .1535$ ) and a little thinner walls $-1.5-1.9 \mu \mathrm{m}$. The authors consider these differences as insufficient for distinguishing a separate species or form. The features concerning all samples have been included into the Table 1 . 


\section{Tarichium tatricum n. sp.}

Resting spores smooth, regularly globose of the diameter (14.1)-15.5-15.9$-(20.0) \mu \mathrm{m}$, transparent with finely granular content and with the walls about 0.5 $\mu \mathrm{m}$ thick, forming of irregularly globose, thin-walled hyphal bodies of the dimensions (14.1)-15.5-17.3-(18.7) $\times 15.5-16.5 \mu \mathrm{m}$ occurring inside the idiosoma of a host in the catenulate arrangement. In the basal joints of the legs there were only few resting spores. Hyphae and conidial sporulation lacking.

In the dead deutonymphe of a mite of the sub-order Parasitiformes found in the mountain pasture in Dolina Miętusia, the Tatra National Park, on 9 September 1982 . The type signed with the $\mathrm{N}^{\circ} .1477 \mathrm{~d}$ in the collection.

Diagnosis (Pl. V a-b). Sporcie perdurantes leves, regulariter ylobosale diantro (1+1)-15.5-15.9-120.0) jem, hyalincie, tenue-granulosa plasma impletac, cum membrana circa $0.5 \mu$ m crassu, ex irregulariter globosis corporis hyphatis dimensionibu (14.1)-15.5-17.3-(18.7) $\times 15.5-16 \mu \mathrm{m}$ in catenulato ordine intra hospitis idiosomo formantur. Sporulatio canidialis et hyphae absunt.

In mortua deutonympha dcarorum subordine Parasitiformes in Dulina Mietusia (Tatra mons) die 9 mense Septembri anno 1982 coll. Typus mumero $1477 \mathrm{~d}$ in collectione designatus.

This species is easily distinguishable among the forms with smooth-walled resting spores by their very constant, relatively small diameter ind invariably globose shape

\section{Tarichỉum teauiparietatum n. sp.}

Resting spores colourless, smooth. globose of strongly differentiated dimensions - (9.0)-14.4-16.0-(23.4) $\mu \mathrm{m}$ in diameter - with the content formless, transparent, surrounded by the walls $0,5-1.0 \mu \mathrm{m}$ thick. Conidial sporulation and hyphae unobserved.

In a dead mite of the group Oribatei form a nest of Formica polyctena Först. found in the coniferous forest Piotrowo, forest district Oborniki, on I June 1982. The type signed with the $\mathrm{N}^{\circ}, 1530$ in the collection.

Diagnosis (Pl. V c-d). Sporae perdurantes leves, hyalinae, globosae, $t$ alde differentibus dimensionibus, diametro (9.(1)-14.4-16.(0-123.7) um, membram 0.5-1.0 um crassa comentae, corpus hos pinis implent. Sporulatio conidialis ef hyphae non inentae sunt.

In mortuo acaro e subordine Oribatei in cumiculo Formicae polyctenae in silvi conifera Piotrowo prope Oburniki die I mense I unio anno 1982 coll. Typus numero 1530 in collectione desiynatus.

This species differs from T.sphaericum n. sp. by considerably thinner walls and from T. tatricum n. sp. - by strong differentiation of the dimensions and internal structure of the resting spores. It is entirely different from any other species. 
Tarichium tenuisculpturatum n. sp.

Resting spores light yellow to golden-yellow in mass with formless, transpaIt content, globose of the diameter (23.0)-29.8-31.7-(37.4) $\mu \mathrm{m}$, surrounded with : walls $3.5-3.9 \mu \mathrm{m}$ thick. The epispore with delicate and moderately dense llow pitts, appearing to be punctate with a fine rugosity. The resting spores fill : host's body cavity and basal joints of its legs and gnathosoma. Conidial rulation and hyphae lacking.

In dead mites Pergamasus sp.: N $\mathrm{N}^{\circ}$. $1477 \mathrm{a}$ - collected under the Scotch pine $k$ in the coniferous forest Borek, forest district Wronki, on 7 April 1982; No. $77 \mathrm{~b}$ - designed as the type - collected in the ant hill of Formica rufa $\mathrm{L}$. in the uiferous forest Piotrowo, forest district Oborniki, on 20 Mai 1982; $\mathrm{N}^{\circ} .1537$ lected in the rotten wood for the hollow in Robinia pseudacacia $\mathrm{L}$. in the ndrological Garden of the Academy of Agriculture in Poznani-Sołacz, on March 1983.

Diagnosis (PI. VI a-d, VII a-b). Spore perdurantes pallide- vel aureo-fulvae, bosae, diametro (23.0)-29.8-31.7-(37.4) $\mu \mathrm{m}$, indiferente hyalina substantia intercum membrana 3.5-3.9 um crassa, episporio tenue ruguloso et modernato denso lose sinuato, corpus hospitis una cum basalibus articulis extremitatum implent. rulatio conidialis et hyphae absunt.

In mortuis acaris Pergamasus sp.: $N^{\circ} .1477 a-$ sub cortice Pini silvestris in a conifera Borek prope Wronki die 7 mense Aprili anno 1982 coll.; $N^{\circ} .1477 \mathrm{~b}-$ us designatus - in cuniculo Formicae rufae in silva Piotrowo prope Oborniki die mense Maio anno 1982 coll.: $N^{\circ} .1537$ - in ligno putrido Robiniae pseudacia in rto Dendrologico Academiae Agriculturarum in Posnania die 30 mense Martio 1o 1983 coll.

This species differs from T. acaricolum n. sp. by the smaller resting spores and tinctly finer surface ornamentation of the epispore. In this respect it sh " $u \mathrm{~d}$ be nparable with $T$. subpunctulatum B a 1 a z y (1982a), however, the rugosity he resting spore surface (PI. VII a-b) and lack of rhizoids in T. tenuisculptura$2 \mathrm{n}$. sp. as well as too distant hosts do not allow to treat these fungi as identical.

\section{Some unidentified forms}

1. Black, entirely opaque, strongly warted on the surface structures were ierved in a dead specimen of Oribatei found on 30 March 1983 in the rotten tter taken out from a hollow in Robinia pseudacacia in the Dendrological rden in Poznan-Sołacz. The dimensions of these stuctures, resembling newhat dark Tarichium resting spores, were (16.4)-21.9-23.6-(32.0) $\mu \mathrm{m}$, with the thmetic mean $22.7 \pm 3.11 \mu \mathrm{m}$ (PI. VIII a-b). For the reason of poor condition of i material the full characteristics and essential description were impossible. 
2. In two cases capillispores of unidentified species of the genus $N$ Witlaczil $[=$ Triplosporium (Thaxter) Batko] attached to the legs or seta mites were found. They were first found on a deutonymphe of a species o order Parasitiformes. collected in the coat of a small rodent Microtus ar: in the Wielkopolski National Park, protected area Wiry, on 2 Febru. The capillispores were relatively big, 18.7-29.6 × 8.5-12.5 $\mu \mathrm{m}$, strongly i basal parts with the haptors $1-2 \mu \mathrm{m}$ long. With regard to the shape and should be comparable with those of N. ietranychi (Weiser) Rem. et Kell., was no roughness on their surface. In the second case similit but sm more slender capillispores, 11,7-17.2 $\times 3.5-5.6 \mu \mathrm{m}$ were found on a Lasioseius ometes (Oudemans) collected under the pine bark in t Rakownia, forest district Zielonka, on 7 April 1982. With regard to the s size these spores were incomparable with any of the known species of $N$ from mites ( 1. VIII c).

3. The most common in dead specimens of Pergamasus sp. [in one species $P$. septentrionalis (Oud.) was determined] was the fungus relatively big globose or ovoidal durable structures (45)-65-82-(111 diameter or $60-108 \times 39-75 \mu \mathrm{m}$, covered with the yellow or light=t smooth wall 2.5-6.0 $\mu \mathrm{m}$ thick (PI. VII e-f). The content of these cells was t finely granular, not transparent, staining well with aniline blue in lac and with aceto-carmine, but the nuclei were not disting (Fig 1; Pl. VII d, f). If above described structures were formed in particu of legs or gnathosoma they assumed the shapes determined by the exosk these parts of the host body (Fig. VII g). Occurrence of this fungus was the following collections: in Pergamasus sp. from an ant-hill of For group in forest district Babki, forestry Łękno, on 21 Mai 1980; in Perga. and two specimens of $P$. sepientrionulis (Oud.) under the bark of a pine the forest district Wronki, forestry Borek, on 7 April 1982; in 6 spec Pergamasus sp. collected in the hills of Formica rufa (L.) in fores Oborniki, forestry Piotrowo, on 20 Mai 1982; in Pergamasus sp. under in the Dendrological Garden of the Academy of Agriculture in Poznan-s 23 March 1983; in Pergamasus sp. from rotten spruce wood and in Trich. ovalis (C. L. Koch) from that rotten pine trunk - both in the fores Grodzisk. forestry Zwierzyniec, on 6 April 1983. Apart from the above m collections similar structures were sometimes found among the remnant: unidetified mites and in one case in a small staphylinid beetle.

Several attempts to isolate and cultur this fungus were made, but or growth in the dead mites in damp chamber conditions was succes mycelium was usually abundant, consisted of thread like, colourless, nc 


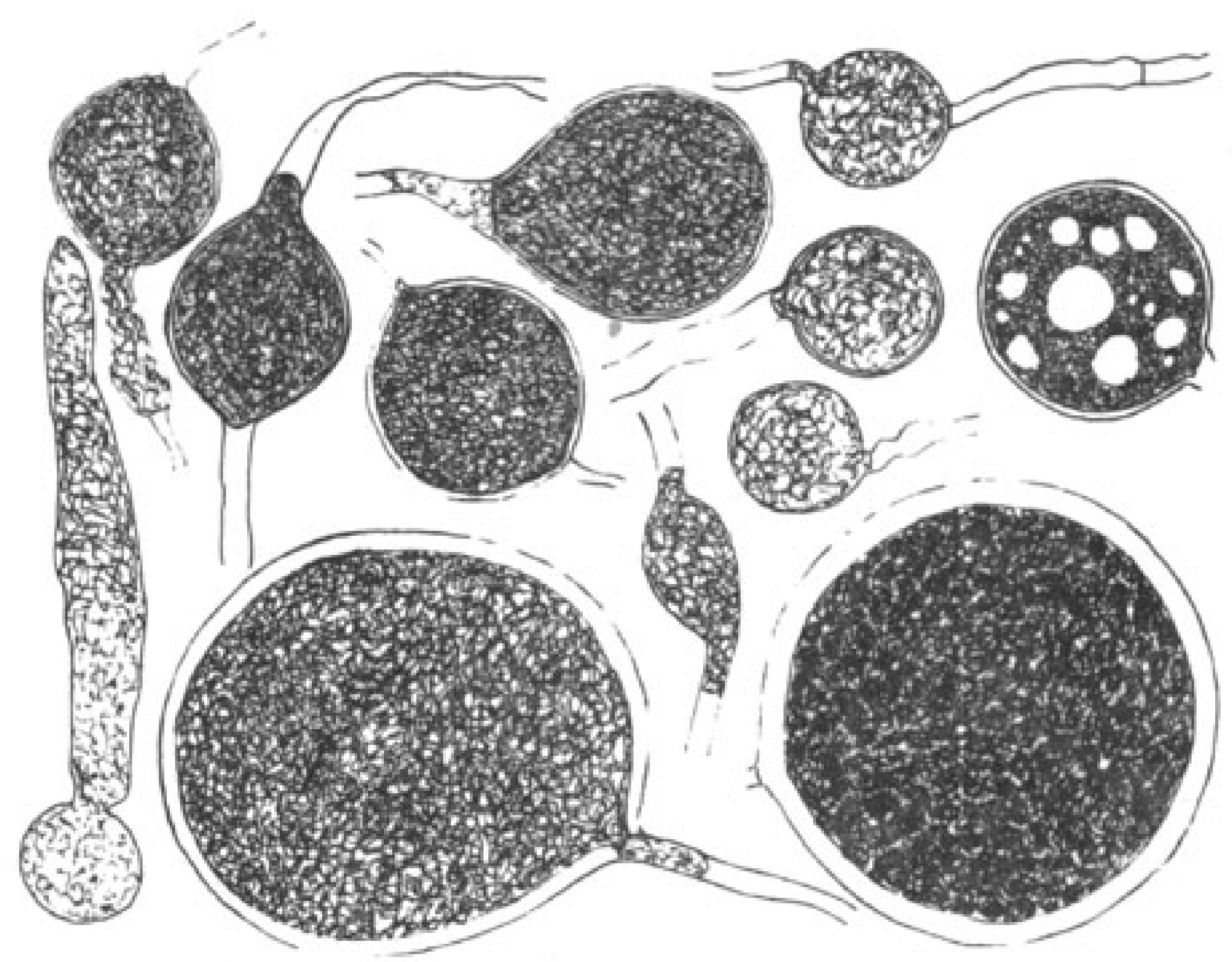

Fig. 1. Pythim-like mycelium with elements of vegetative phase

and poorly branched hyphae of uniform diameter (0.8)-3.1-4.4-(8.6) $\mu \mathrm{m}$, with numerous intercalar and few terminal, at first thin-walled giant cells, spherical, ovoidal or elongated (Fig. 1; Pl. VII d), diameter 11-60 $\mu \mathrm{m}$, with age partially degenerated or changing into thick walled structures described above. Both in the damp chambers and in hanging drops no new elements either of the fungus development or its morphology were obtained. Although the identification of the fungus on this basis is not possible it seems to be very close to the genus Pythium Pringsheim and in some respects resembles the structures described by $\mathrm{T}$ h or (1930) as Hermanniasporidium magnum ST. H öl Id o b I e r (1933) and Es p a d a 1 e r (1982) noticed the similarity of the latter to Myrmicinosporidium durum Hölld. - the parasite of some ant species. It would be interesting to determine the systematic position and ecological significance of this fungus which seems to be rather common in the biotic communities of the forest floor.

4. In one dead Pergamasus sp. collected together with the rotten wood from the hollow in Robinia pseudacacia in the Dendrological Garden in Poznan on 30 March 1983 there were found numerous thick walled structures irregularly star-shaped in outline, of the diameter $8.1-12.5 \mu \mathrm{m}$. The round central part 6.3-7.0 $\mu \mathrm{m}$ in diameter, contained a subglobose vacu le of the approximate size $4.7 \mu \mathrm{m}$ 
surrounded by $1.5-2.5 \mu \mathrm{m}$ thick layer of the condensed protoplasm, was.covered with a hyaline wall $1.5-2.5 \mu \mathrm{m}$ thick having relatively long, obtuse warts and outgrowths up to $3 \mu \mathrm{m}$ long on its epispore (Pl. VIII c). These structures have been surely the zygospores of a species of Zonpagales, however, neither invaded amoebae nor other vegetative elements of the fungus were observed.

\section{CONCLUSIONS}

On the basis of the data concerning the fungi parasitic for mites or dispersed by these arthropods one can state that the investigations on these problems are scarcely in the starting point. It seems, however, that the diversity of the forms and species of the fungi infecting mites is not lesser than in the case of the insect killing fungi. Unfortunately, the fungal diseases of the mites are usually either overlooked by acarologists or described imprecisely, precluding a correct identification of the pathogens. The most convenient form for elaboration of similar problems should be permanent and close co-operation and exchange of information between acarologists and invertebrate pathologists. The development of such comprehensive studies should cause reliable progress in invertebrate pathology on the whole. In the range of the mycology it should contribute to the fuller knowledge of the phylogenie of entomopathogenic fungi, in particular of Entomophthoraceat.

The authors express their thanks to the M. Sklod wska-Curie Found fir financing it part of the investigations concerning the mites octurrin in ant nests within the research project $\mathrm{FG}=1 \cdot \mathrm{O}-366$. The authors are also indebted to Stawomir $\mathrm{K}$ a $\mathrm{c} z \mathrm{~m}$ a $\mathrm{r} \mathrm{e} \mathrm{k}$, M.S. (Polish Atademy of Sciences, Department of Agricultural and Forest Bioligy in P. znañ) for the mite infe ted with Tari hium Iatricum n. sp. and to Teresa $\mathrm{F}$ a b is za $\mathrm{k}$ M. Ph. (A. Mickiewicz University in Poznani) for preparation of $f$ atin descriptions $f$ the new species.

\section{REFERENCES}

B a I a z y S, 1976, Some noteworthy necrophytic fungi isolated from arthropods. PTPN, Pr. Kom. Nauk. Rol. Les. 42: 3-17.

B a I a z y $S_{4}, 1978$, A new species of Entomophthoraceae (Mycophyta: Entomophthorales) from Poland. J. Invertebr. Pathol. 31: 275-279.

B a $\$ a z y $S_{4}, 1982 a$, New species of Entomophthoraceae from the Wielkopolski National Park. Bull.

Acad. Pol. Sci. Ser. sci. biol. Cl. II.. 29: $221-226$.

B a I a z y $\mathrm{S}_{4,}$ 1982b, Entomophthoraceous fungi on parasitic Hymenoptera. Ibidem: 227-230.

Batazy $S_{4}$ W isniewski J., 1977, A new to Poland species of Entom phthoracede (Mycophyta) from the mite Veigaia sp., PTPN Pr. Kom. Nauk. Rol. Leś., 46: 3- 6.

Ba tazy $\mathrm{S}_{\text {., }}$ Wisniewski J., 1982, Two species of entomopathogenic fungi on the myrmecophiiic mite Trachyuropoda coccinea (Michael, 1891) (Acari: Uropodina). Bull. Acad. Pol. Ser. Sci. biol. 30: $81-84$.

E g i n a K. Ja., T s in o v s k i i Ja. P., 1980, Rezultaty proverki effektivnosti griba Entomophthora thaxteriana (Petch) Hall et Bell na tjach i pautinnych hlescach posle ego chranenja 
[in:] Biologičeskoj metod borby s vrednymi nasekomymi i klešcami, Edit. A. V. Chrameeva, Riga: 7-11.

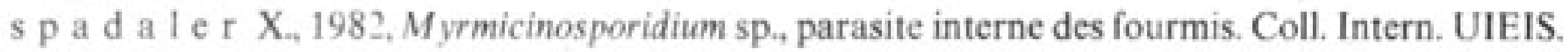
Barcelona: $239-241$.

o 1 I d o b I e r K., 1933, Weitere Mitteilungen über Haplosporidien in Ameisen. Z Parasitenk, 6: $91=100$.

o v a 1 E. Z, 1974, Opredelitel entomofilnych gribov, Kiev, $260 \mathrm{pp}$.

a g e r h e i m G., 1898, Mykologische Studien. I. Beiträge zur Kenntnis der parasitischen Pilze. 1-3. Bihang. Till. K. Sv. Vet. Akad. Handling. 24: 3-22

i in d q u is t E. E., 1961, Taxonomic and biological studies on mites of the genus Arctoseiws Thor from Barrow, Alaska (Acarina: Arctoseidae). Hilgardia 30: $301-350$.

i p a J. J., 1962, A review of diseases and microbial control of mites (Acarina). Biul. Inst. Ochr. Rosl. 18: $175-202$.

i p a J. J., 1971, Microbial control of mites and ticks (in: Microbial control of insects and mites. Ed. H. D. Burges and N. W. Hussey, London and New York): 357 - 373.

I a c L e od D. M., M ü II e r-K ög I e r E., 1970, Insect pathogens: species originally described from their resting spores mostly as Tarichium species (Entomophthorales: Entomophthoraceae). Mycologia 62: $33-66$.

e m o to $\mathrm{H}_{4,}$ A o $\mathrm{k}$ i J., 1975, Entomophthorafloridana (Entomophthorales: Entomophthoraceae) attacking the sugi spider mite, Oligonychus hondoensis (Acarina: Tetranychidae), in Japan. Appl. Ent. Zool. 10 (2): $90-95$.

e t c h $T_{n,}$ 1944, Notes on entomogenous fungi. Trans. Brit. Mycol. Soc. 27 (1-2): $81-93$.

a $\mathrm{m}$ s i h a $\mathrm{k} \mathrm{K}$., 1962, Interessante Milbenfunde aus der Umgebung von Sobotka - Nordostböhmen. Acta Mus. Reginaehr, S. A: Sci. Nat. 1-2. IV.: 77-87.

ho f $\mathrm{S}_{1,}$ 1933, Uber einzellige Parasiten in verschiedenen Acarina, I. Z. Parasitenk. 2: 551 - 570.

sintsa dze K. V., V a it a p e t o v S. G., 1976, Novyi entomopatogennyi grib Entomophthora adjarica sp. n. (Phycomycetes, Entomophthoraceue), poražajušcii obyknovennogo pautinnogo klešca Tetranychus urticae Koch. Bull. Acad. Sci. Georg. SSR 83 (2): $465-468$.

\section{O niek tórych grzybach niższych występujących na roztoczach (Acarina) w Polsce}

\section{Streszczenie}

W wyniku badant nad chorobami roztoczy wystepujących w mrowiskach, sciólce lesnej oraz w rowiskach owadow podkorowych i w cześciowo rozlożonym drewnie autorzy - badając glównie chowane w martwych osobnikach zarodniki przetrwalnikowe - wyodrębnili 11 gatunków zybōw nižszych, z k tốrych 9 stanowią nowo opisane taksony. Z wyjątkiem gatunku Erynia lalangicida (Lagerh.) Rem. et Henneb., który wytworzyl typowe zarodnikowanie konidialne, zzostale zaliczono do rodzaju Tarichium Cohn, grupującego owadomorki (Entomophthorales) o ekompletnie poznanej morfologii i rozwoju.

Na podstawie obliczeń statystycznych materiałów uzyskanych w wyniku pomiarów oraz crególowych badań mikroskopowych sporz̨dzono tablicę poglądowq o stopniu zróżnicowania rm zaliczanych do rodzaju Tarichium, poznanych dotychezas z roztoczy, oraz ulatwiljąca ich naczanie.

Można przypuszczać, że choroby grzybowe wśród roztoczy występują nie rzadziej niż wśród wadów oraz, że w obu grupach powodowane sa przez pokrewne gatunki patogenów. 